\title{
Challenges to Women's Participation in Senior Administrative Positions in Iranian Higher Education
}

\author{
Bahieh Mohajeri $^{1} \&$ Farah Mousavi $^{1}$ \\ ${ }^{1}$ School of Education, Al-Zahra Farhangian University, Zanjan, Iran \\ Correspondence: Farah Mousavi, School of Education, Al-Zahra Farhangian University, Zanjan, Iran. Tel: \\ 91-2241-9438. E-mail: F.Mousavi44@yahoo.com
}

Received: February 22, 2017

Accepted: April 5, 2017 Online Published: July 29, 2017

doi:10.5539/ies.v10n8p77

URL: https://doi.org/10.5539/ies.v10n8p77

\begin{abstract}
In the last three decades, growth in the education of women in Iran has led to a significant increase in demand for women professionals and administrators in Iranian universities. However, the path to the top is not easy and numerous challenges must still be overcome. This study explored the challenges of women's participation in senior administrative positions from the perspective of Iranian women administrators in higher education. Data were collected based on semi-structured interviews with 20 women academician in administrative positions. Thematic analysis was conducted to examine the themes that emerged to represent their experience and perspective. The findings indicated that challenges ranged from organizational to societal and individual factors. Individual factors were related to personality traits such as work-family balance issues and a lack of selfconfidence. At the organizational levels, difficult relationships at work and the old boys' network, and organizational practices were perceived to be a hindrance, while at the societal level, gender role stereotypes and social attitudes towards women were viewed as key challenges to the participation of women in senior administrative positions. The implication for women who aspire to the top position of organizations is that they should be aware of and understand the visible and invisible challenges in relation to their career advancement.
\end{abstract}

Keywords: women academician, challenges, administrative positions, higher education

\section{Introduction}

On the global level, reports demonstrated that women as students, professors, and administrators has increased from the second half of the last century, however it does not mean gender parity has been achieved in all parts of higher education systems. Women are still unacceptably underrepresented in some fields, especially in senior administrative positions, in some parts of the world (Altbach, 2010).A review of some studies on women's career advancement reveals that women are still significantly under-represented at top management level worldwide (Yukongdi \& Rowley, 2009; Collings et al., 2010; The World Bank Group, 2014). In some cultures, especially in Eastern countries and Middle East, women have been placed in supporting roles to men, such as homemaker and nurturer, which reflects a form of sex role ideology (Eagly, 2013). However, there are notable examples of these developing countries in which some women have managed to reach management positions. Iran is one such example (Hosseini, 2008; Ismail \& Rasdi, 2006; Yukongdi \& Rowley, 2009; Abdalla, 2015) and is the focal point for the present study. During the past decade, Iran has experienced intense growth in women's education leading to a significant increase in demand for women professionals and administrators. As women become more educated and qualified for managerial positions, the number of Iranian women managers and executives are predicted to rise over the next decade, but only a very small proportion of women academicians advance to administrative positions (Ministry of Science, Research and Techonlogy, 2015). A recent survey reported that the proportion of women in senior academic administrative positions in Iranian higher education was less than 5\%, considerably below the global average of 22 percent (Thornton, 2015). While it is possible for Iranian women to achieve 'senior administrative positions', the path to the top is not easy and numerous challenges must be overcome if success is to be achieved. Even when a relatively senior position is reached, there may still be difficulties ahead as some research studies have suggested (Lyness \& Thompson, 1997; Hosseini, 2008). The current study aims to identify the challenges encountered by women academicians in administrative positions in universities in Iranian cultural context. Through in-qualitative approach, the study seeks to gain an insight into the career experience of a small number of women, specifically, how these women have managed to overcome 
the challenges and to move toward administrative positions in universities.

\section{Literature Review}

The research on women in administrative positions within countries, especially in developing countries, has been a significant area of study since the 1980's (Oplatka, 2006). Over time, scholars have addressed issues of internal and external challenges for women's participation in administrative positions of higher education in developed and less developed countries (Shakeshaft, 1989; Acker \& David, 1994; Oplatka, 2006; Costello, 2012; Morley, 2014). According to existing reviewed literature three key factors in career participation of women in top administrative positions are determined including cultural, organizational and individual factors.

\subsection{Cultural Factors}

Earlier researches examining the pressure of cultural values on women's career development worldwide have mostly demonstrated that cultural values are expected to block more than support women administrators in higher education (Martin, 1992; Harrison \& Huntington, 2000; Cubillo \& Brown, 2003; Dimmock \& Walker, 2005; Orser et al., 2012; Hoeritz, 2013; Batool \& Sajid, 2013). For example, in a cross-cultural study, Cubillo and Brown (2003) explored the life experiences of females in higher education in the UK from different countries and realized that European women who grew up in Western societies did not experience cultural values as obstacles, but women from Middle East and Africa considered that in their culture, women are still considered mainly as family child bearers and responsible for taking care of family members.

Researchers have shown that women, particularly those in traditional societies, are expected to take more family responsibilities than men. Such expectations have been found to be a huge challenge in academic career development for women academicians in Turkey (Neale \& Özkanl1, 2010), Pakistan (Batool \& Sajid, 2013), Thailand, Hong Kong, Singapore, and Malaysia (Luke et al., 2003), Kenya (Olser, 1997, cited in Oplatka, 2006), Iran (Hossieni, 2008) and even for Asian American Pacific Islanders (Chen \& Hune, 2011) and African American women (Blackwood \& Brown-Welty, 2011).

The previous studies also describe the role of stereotypes in women participation especially in managerial positions. Stereotypes such as 'think manager-think male' are a deep-rooted view, particularly among men (Schein, 2001). This cultural phenomenon translates even well into the academic environments as "think professor-think male" and "think chancellor-think male" (Tharenou et al., 1994). Such considerations not only constrain women's admission to leadership positions but also build prejudiced evaluations when women occupy such roles (Heilman, 2001; Mabokela, 2003; Bailyn, 2003; Eagly \& Carli, 2007; Eagly, 2010).

The mentioned literatures raise questions about the strategies that successful women in senior administrative positions apply to cope with the challenges enforced by stereotypes and cultural values, and especially how women academicians who desire to be appointed as senior administrators tolerate the pressure between cultural values about expectation of gender role and career purposes.

\subsection{Organizational Practices}

The huge volume of literature provides evidence of how organizational norms and structures affect women in their career progression (Vaira, 2004; Harris et al., 2011; Nguyen, 2013; Parker \& Welch, 2013; Stalker, 2013; Wajcman, 2013; Peterson, 2014). The previous researches on the links between organizational structure and women's participation in senior administrative positions points to three important factors: mentoring, networking, and promotion practices.

The influence of mentoring on women's participation in managerial positions is the more investigated subject in the studies on women's profession development in universities (Harris et al., 2011). Most researches, by focusing on the mentors and women administrators, disclose that mentorship may be one of the great motivations for career advancement of women (Blum et al., 1994; Brown, 2005; Beck, 2008; Kiamba, 2008; Madson, 2008; Airin, 2010; Collings et al., 2011; Harris et al., 2011; Walts, 2012). Findings showed that women who were appointed to administrative positions in the academic workplace need support from other professional administrators in their department to adjust to their profession and to recognize the structure of the department (Beck, 2008). It is significant to explore how in Iranian cultural background, mentorship helps women academicians to develop their occupations into administrative positions.

Indeed, researchers have argued for developing and establishing multiple relationships in workplace, and how these ways may be an important career-building strategy (Burt, 2000; Higgins \& Kram, 2001). Moreover, Tharenou (2001) maintained that administrators, especially women, need social ties and networks in their institutions when attempting to progress to higher career positions, because women's access to resources and information is limited in work place. The present study has made a point to examine how formal and informal 
organizational networks, especially the 'good old boy networks' applied universally, has affected Iranian women with a cultural background in senior administrative positions.

Organizational culture may really consider the complexity of exploring whether women are discriminated against in appointment and promotion practices. Existing literature on career development of academic women into senior administrative positions in most Eastern universities shows that women are less eligible for promotion because of the challenges of family and professional life (Lam, 2006; Ismail \& Rasdi, 2006; Hossieni, 2008). A large study on Turkish higher education by White and Ozkanli (2011) showed organizational norms, structures, and values are perceived as challenges to women's career development. In Hong Kong, although general management training programs are provided, and training specifically for women managers was often a university priority, it does not fit well with most women's schedules. For example, workshops on weekends and the culture of long hours make it difficult for women who have family commitments (Cheung \& Halpern, 2010).

Iranian universities, especially governmental universities, are centralized and bureaucratic (Welch, 2011). However, there is a lack of studies on women's career development in Iranian universities that specially address how organizational culture affects appointment and promotion policies. Appointment for senior administrative positions in Iranian higher education may be different from other parts of the world. Consequently, it will be necessary to explore how women faculty members navigate their career path toward administrative positions and how is the promotion process in centralized and bureaucratic systems of universities in developing countries like Iran.

\subsection{Individual Factors}

In the literature related to women's career development, individual factors are seen as strong determinants for academic administrators in accomplishment of career responsibilities. Personal attributes as one of the most constant arguments in previous studies on women's career development worldwide is considered a constraint or a motivating factor to career development.

Most of the findings from Western and Eastern higher education are the same. Many personal attributes which are more likely to help women in accomplishing duties in administrative positions include collaborative style (Bornstein, 2007; Madsen, 2008), more people-oriented (Eagly et al., 2001; Vinkenburg et al., 2011), assertiveness (Williams, 1993), adaptability, determination, self-motivation, confidence, and independence (Wolverton \& Gmelch, 2002; Lam, 2006; Ismail \& Rasdi, 2006; Madsen, 2008; Wajcman, 2013; Oplatka, 2006; Eagly \& Carli, 2007; Heilman, 2001; Schein, 2001), and having a higher commitments (Johnsrud \& Heck, 1994; Lam, 2009; Wajcman, 2013). Many scholars demonstrated that women having the above mentioned personal attributes are more likely to tolerate higher responsibility career positions in higher education. In addition, personal traits such as attitude toward work, communication skills, ability to work hard, and problem-solving skills are the other individual factors that can help women in career development (Ismail \& Rasdi, 2006; Lam, 2009; Beck, 2008; Gray, 2011).

A huge amount of literature on career development of women in Western counties has discussed the impact of having professional skills and education on career development (Rosser, 2003; Umbach, 2006, 2014; Gray, 2011b). Literature further considered qualifications as a major factor to women's career advancement, reporting that higher qualification was a great opportunity in women's pursuit of successful career trajectories, especially advanced qualifications' which have helped women excel in a male dominated world (Ross \& Green, 2000; Steinke, 2006; Hoobler et al., 2014; Gray, 2011). Hartley and Godin (2009) cited that, in their study, the presidents of colleges who had experience in administrative positions felt strongly that their prior experience was the best training for their presidency. Ross and Green (2000) in North American higher education reported comprehensive information on the educational background of American college presidents. They showed that in 1999, close to 60 percent of presidents had a doctorate degree. According to the theories of cultural capital, training and education as human capital can be the key factors in career mobility of women (Rosser, 2003; Umbach, 2006; Bourdieu, 2008;Morley, 2014).

Even though there have been some common arguments with respect to challenges for female administrators in academic workplaces, they are not necessarily universal common themes. These differences may indicate the key important role of socio-cultural context in determining what facilitates or hinders women's career path toward senior administrative positions. Therefore, it is very important to extend our understanding in different socio-cultural contexts.

\section{Methodology}

A qualitative approach with purposive sampling technique was employed. Data were collected using 
semi-structured, in-depth interviews with the participants. A total of 20 women in administrative positions in universities occupying positions of Vice-President, Vice-Faculty, and Head of departments participated in the study. The interviews took place at the women administrators' office. These women had a mean age of 55 . Fifteen of the participants in the sample were married and five were single. The women administrators were asked to identify the challenges to their career advancement. Thematic analysis with Nvio software was conducted to examine the themes that emerged to represent their experiences and perspectives.

\section{Findings and Discussion}

The valuable findings obtained through analyzing the data indicate themes and some subthemes which highlighted the challenges of women's participation in senior administrative positions in university. The challenges for female senior administrators in Iranian universities were created by a number of different factors. The key findings indicated that challenges included the issues of relating gender role expectations to work-family balance and a lack of career aspiration; societal factor such as gender misconception; lack of strong personality for applying to senior academic administrative positions, lack of supportive organizational policies and unfriendly organizational relationship, all of which were indirectly discriminatory against women administrators. These challenges helped explain the lack of women academicians at senior administrative positions in Iranian university.

In this research, some of the challenges that women administrators experienced were resonated with most previous literature from around the world; most of the challenges include challenges regarding women's prescribed duties and their professional academic demands and heavy workload as lecturers and administrators (Luke et al., 2003; Lee, 2001; Letherby, 2006; Eagly, 2007; Madsen, 2008, 2012; Neale \& Özkanl1, 2010; Eagly et al., 2011; Ramsay and White, 2011; Harris et al., 2011; Blackwoodet al., 2011; Nguyen, 2013; Morley, 2014; Baruch et al., 2014; Peterson, 2016). However, the results of this study make a valuable contribution to the discussion, because the findings reveal the specific influence of socio-cultural values in the Iranian context on challenges for women academicians in senior administrative positions. Therefore, findings from this study disclose the perception of women's administrators in Iranian universities.

Academic literature on women academic administrators revealed that the priority of family obligations act as the strongest challenge to women academicians who want to move in administrative positions (Luke, 2000; Oplatka, 2006; Eagly \& Carli, 2007; Madsen, 2008; Neale \& Ozkanli, 2010; Turner, 2011, 2012; Eagly, 2012; Peterson, 2014; Afiouni, 2014; Evetts, 2014). The finding of this study is in agreement with previously mentioned literature which believes women, mostly because of traditional gender role expectations, more than men are expected to tolerate home responsibilities such as care of children, husband, aged parent and the obligatory house work, even if they are managers in their career. As a result, women in Iran are unwilling to become more engaged in public domains or accept highly responsible career positions as long as they prioritize family roles. This finding is aligned with what Hossieni (2008) found in her study in Iran. The literature in Iran shows that there is strong support in Iranian society to keep gender role expectations completely separate. Due to commitment to socio-cultural norms in Iran, both women and men seem to accept that the professional roles of women are secondary to the household roles.

On the other hand, at the individual level, the participants in this study asserted that women lacked confidence for applying to senior administrative positions such as Dean or President. The participants thought that positions with very high responsibility such as President and Dean are only for men colleagues. They felt it was unfortunate that some women colleagues were eligible and capable of being Dean and President, but they were unwilling to move into very high administrative positions because they lacked confidence and were not courageous enough to deal with challenges. Similar finding are also seen in the literature (Oakley, 2000; Schein, 2001; Eagly \& Carli, 2007; Heilman, 2012; Gilligan, 2013). These findings are in favor of the perspective that asserted that women have attitudes, behaviors, cognitions, and personality traits that are not appropriate for leadership positions (Riger \& Galligan, 1980; Fagenson, 1990, 1993; Parker \& Fagenson, 1994).

A number of studies have suggested that gender lack of confidence may be reduced if women have the chance to work with or be mentored by female senior management because women learn and experience from role models (Anderson, 2005).

At the organizational level, in spite of equal practices in organizations, especially in higher education, women's progress has been restricted because the persistence of cultural gender role expectations in organizational culture makes it difficult for women academicians to make full use of their capabilities in career development (Wood et al., 2009; Acker, 2012; Bagilhole \& White, 2013; David, 2013). This literature is supported by findings of this research. Women participants used a variety of notions to express the gender inequality in senior administrative 
positions in their own way of understanding and their own experiences or experiences of women they knew.

Some of the institutional practices such as scheduling of meetings after long hours of work were found to be more insensitive to women administrator's situation as house wife. Some of these practices may have certain costs for some of the women administrators who also have family responsibility, as family members could not stand women coming back home too late or women having to attend meetings on weekends. Although all women administrators generally accepted pressures of administrative responsibilities, the majority of them made a point of stressing that they as Iranian women need to achieve a balance between work and life, and that a few of them had some family difficulties as a result. This issue was also found in previous studies by (Rosser, 2004; Probert, 2005; Hosseini, 2008; Lam, 2009; Airini et al.,2011; Murniati, 2012; Gmelch, 2014;Morley, 2014).

They furthermore indicated that women indeed had to work harder to become leaders, because women managers face huge challenges of having two inconsistent roles, one as a housewife and one as a professional in work setting. They asserted that they were capable to manage immense duties in family and university. In addition, they made a great commitment to be successful by relying only on their individual initiative and strengths. The finding is aligned with Madsen's (2012) assertion that life is never equal for women. Women faced greater challenges than men, but women have better chances to be successful because they are hard working. This is very important for young women academicians and female students desiring to be in administrative positions in universities. They could learn and imitate from them as role model or informal mentors.

Cheung and Halpern (2010) indicated that university policies and structures in practice may help, but they may not remove constraints for gender equality if the social constraints against women are not emended. Therefore, this finding suggests that developing career advancement programs for Iranian women may be a subject that needs social change rather than more equal practices in organization level or the western strategies such as affirmative action. Hence, programs and laws for women's advancement in career have not been effective. As Rezai-Rashti and Moghadam (2011) argue, only providing women with higher education will not facilitate women's access to higher employment positions without social transformation of cultural gender role expectation that perpetuate inequities.

Relationships concerns within university such as male networking, and lack of mentors, were major challenges for women's career development. Keeping women out of "old boy" networks is cited as a constraint to progression into senior administrative positions by some previous studies (Oakley, 2001; Ballenger, 2010; Whiteet al., 2012;Burke and Mattis, 2013; Lie and Malik, 2014). Ballenger (2010) confirmed that in general, male leaders tended to be supportive to other men because they have a tendency to prefer people that are similar to themselves. In this study, "old-boys" network or informal men's groups were reflected by most participants as feeling barred from the informal networking within their university and describes how women administrators were usually excluded from decision-making process in informal meetings. The participants clarified how women were marginalized by cultural norms from informal men's networks and they could not contribute in informal meeting with men colleagues due to social constraints. The literature also indicates this issue that women in most Islamic countries are marginalized and still subject to feminine demarcations in informal masculine networks (Shah and Sobehart, 2008; Barlow and Akbarzadeh, 2012; Musai et al., 2014; Abdalla, 2015b).

Based on findings from this study, in particular, women were tending to lack formal and informal mentors. Therefore, women academicians and administrators were less well connected to circumstance of work sitting, while women also had less experience and seniority in the administrative positions. This issue is also confirmed by (Beck, 2008; Collin, 2009; Berkovitch et al., 2012). Beck (2008) realized that women academicians who are appointed to administrative positions need more support from male colleagues to understand the structure and culture of the institution and to adjust themselves to administrative positions.

In literature, some scholars established that women require more encouragement than men to pursue their career pathway into senior administrative positions (Eby et al., 2013; Bean et al., 2014;Dunn et al., 2014; Morley, 2014; Johnson, 2015).

A number of studies described that women managers often become mentors for women colleagues (Beck, 2008; Madsen; 2008; Kiamba, 2008; Airin, 2010; Airini et al., 2011; Harris et al., 2011; Beaman et al., 2012; Macfarlane, 2013). Kiamba (2008) showed that having a women mentor may be a positive tool to women who are enthusiastic about seeking management positions. However, some studies on mentoring indicated the phenomenon of "queen bee" (Staines et al., 1974; Lam, 2006; Derk et al., 2016), in which females in higher career positions, especially in management, do not help women colleagues because they want to be unique in top positions or be the only women leaders. 
In this study, all participants acknowledged that women's networking was weak and formal mentoring did not exist in Iranian universities. Women senior administrators were not mentors for other women academicians, and women who were in senior positions did not support other women or took potential junior women in under their wing. However, findings indicated the syndrome of "queen bee". This finding completely coincides with "queen bee" phenomenon that women were not supportive of each other. Higher ranking women did not want to share their experience and spotlight with other women, and therefore were not enthusiastic to assist other women to also be successful.

At the societal level, the female executives mentioned that gender misconception is an invisible challenge for women. In general, gender stereotype relates to the perception that women are inferior to men, it has been argued, due to their lack of masculine traits (Lyness \& Thomson, 1997; Ragins \& Sundstrom, 1989) and women are expected to perform the multiple roles of career woman, daughter, wife and mother (Davies-Netzley, 1998; Lyness \& Thomson, 1997). Women are expected to be humble, respectful, attentive, understanding and discreet (van der Boon, 2003). Gender misconception results in the view that women are not effective leaders because of their lack of masculine leadership qualities (Jain \& Mukherji, 2010, King et al., 2009). Such gender misconception can result in less chance for selection and promotion because of the simple reason that they are women. Iran is low on gender egalitarianism (House et al., 2004), which means inequality could be a source of gender stereotyping.

A number of women's challenges in senior administrative positions resonate very well with literature, but some findings do not seem to be supported literature in other countries. This is a significant point of this study and may be due to socio-cultural Iranian context. This study helped to illuminate the experiences of Iranian women in senior academic administrative positions from a developing country. These research findings can be added to the literature on challenges for women academicians 'advancement' to academic administrative positions in higher education. Such specific knowledge is significant in planning gender equity programs in context of higher education.

\section{Conclusion}

Improving women's participation in administrative positions is an important part of the struggle to improve equality for all women academicians in universities. Therefore, there is clearly a need to have a broader understanding of women's experiences of their career trajectories to senior administrative positions in a qualitative approach with regard to higher education leadership than currently exists in Iran.

The findings of study suggest that women administrators experienced some challenges similar to women administrators in other parts of the world. However, some of findings imply the subtle socio-cultural influence on women in senior administrative positions. The participants expressed that cultural gender role expectations in family and society is the most challenging issue they encountered through their career progression. Cultural factors were more significant than other challenges and beyond the direct control of individual women in this study.

Institutional practices such as promotion process, timing of meetings, heavy workloads as lecturer and administrator were not systematically in favor of women, and sometimes resulted in the lack of women's aspiration to pursue senior administrative positions in university. Organizational environment was not supportive of women. Women did not have mentor and role model because old-boys' network in the university were dominant, while women because of less seniority and experience in administration need to connect to the source's information. Therefore, the researcher believes that gender inequality is a concept held in university at the senior administration level.

The implications for women who aspire to the top position of organizations are that they should be proactive and take responsibility for managing their own career. Women should be aware of and understand the visible and invisible challenges in relation to their career advancement. Also, it is necessary that the challenges be tackled at the organizational and societal levels, which will require the involvement of decision-makers in higher education, policy-makers and changes in attitudes at the societal level towards increasing women's participation in decision making and leadership if Iranian universities are to succeed in enhancing gender equity in academic administration.

\section{References}

Abdalla, I. A. (2015). Career Facilitators and Barriers of Arab Women Senior Executives. International Journal of Business and Management, 10(8), 218. https://doi.org/10.5539/ijbm.v10n8p218

Acker, S., \& David, M. E. (1994). Gendered education: Sociological reflections on women, teaching and 
feminism. Open University Press Buckingham.

Airin, R. (2010). Influencing Factors of Female Underrepresentation as School Principals in Indonesia. Online Submission.

Altbach, P. G. (2010). International Handbook of Higher Education.

Bagilhole, B., \& White, K. (2013). Generation and gender in academia. Palgrave Macmillan. https://doi.org/10.1057/9781137269171

Bailyn, L. (2003). Academic careers and gender equity: Lessons learned from MIT1. Gender, Work \& Organization, 10(2), 137-153. https://doi.org/10.1111/1468-0432.00008

Ballenger, J. (2010). Women's Access to Higher Education Leadership: Cultural and Structural Barriers. In Forum on Public Policy: A Journal of the Oxford Round Table (Vol. 2010).

Barlow, R., \& Akbarzadeh, S. (2012). The Institutionalisation of Political Islam in Iran. Routledge Handbook of Political Islam. https://doi.org/10.4324/9780203154144.ch12

Batool, S. Q., \& Sajid, M. A. (2013). Barriers faced by women managers at universities: A case of Pakistan. International Journal of Managment, IT and Engineering, 3(7), 340-348.

Beaman, L., Duflo, E., Pande, R., \& Topalova, P. (2012). Female leadership raises aspirations and educational attainment for girls: A policy experiment in India. Science, 335(6068), 582-586. https://doi.org/10.1126/science.1212382

Bean, N. M., Lucas, L., \& Hyers, L. L. (2014). Mentoring in higher education should be the norm to assure success: Lessons learned from the Faculty Mentoring Program, West Chester University, 2008-2011. Mentoring $\& \quad$ Tutoring: Partnership in Learning, 22(1), 56-73. https://doi.org/10.1080/13611267.2014.882606

Beck, A. J. (2008). Through the looking-glass ceiling: The advancement of women administrators and women faculty in an institution of higher education.

Berkovitch, N., Waldman, A., \& Yanay, N. (2012). The politics of (in) visibility: On the blind spots of women's discrimination in the academy. Culture and Organization, 18(3), 251-275. https://doi.org/10.1080/14759551.2011.644669

Blackwood, J., Brown-Welty, S., Jean-Marie, G., \& Lloyd-Jones, B. (2011). Women of color in higher education: Changing directions and new perspectives (diversity in higher education). Emerald Group Publishing Bingley.

Blum, T. C., Fields, D. L., \& Goodman, J. S. (1994). Organization-level determinants of women in management. Academy of Management Journal, 37(2), 241-268. https://doi.org/10.2307/256829

Bornstein, D. (2007). How to change the world: Social entrepreneurs and the power of new ideas. Oxford University Press.

Bornstein, R. (2007). Why Women Make Good College Presidents. Presidency, 10(2), 20-23.

Bourdieu, P. (1986). The forms of capital. Handbook of Theory and Research for the Sociology of Education, $241,258$.

Bourdieu, P. (2008). 15 The Forms of Capital. Readings in Economic Sociology, 4, 280.

Brown, T. M. (2005). Mentorship and the female college president. Sex Roles, 52(9-10), 659-666. https://doi.org/10.1007/s11199-005-3733-7

Burke, R. J., \& Mattis, M. C. (2013). Women on corporate boards of directors: International challenges and opportunities (Vol. 14). Springer Science \& Business Media.

Burt, R. S. (2000). The network structure of social capital. Research in Organizational Behavior, 22, 345-423. https://doi.org/10.1016/S0191-3085(00)22009-1

Cheung, F. M., \& Halpern, D. F. (2010). Women at the top: Powerful leaders define success as work+ family in a culture of gender. American Psychologist, 65(3), 182. https://doi.org/10.1037/a0017309

Collin, P. A. (2009). Female special education administrators 'perceptions of mentoring relationships. ProQuest.

Collings, S., Conner, L., McPherson, K., Midson, B., \& Wilson, C. (2011). Learning to be leaders in higher education: What helps or hinders women's advancement as leaders in universities. Educational Management Administration \& Leadership, 39(1), 44-62. https://doi.org/10.1177/1741143210383896 
Costello, C. A. (2012). Women in the Academy: The Impact of Culture, Climate and Policies on Female Classified Staff. NASPA Journal About Women in Higher Education, 5(2), 99-114. https://doi.org/10.1515/njawhe-2012-1118

Cubillo, L., \& Brown, M. (2003). Women into educational leadership and management: International differences? Journal of Educational Administration, 41(3), 278-291. https://doi.org/10.1108/09578230310474421

David, M. E. (2013). Gender, power and management: a cross-cultural analysis of higher education. Gender and Education, 25(4), 528-529. https://doi.org/10.1080/09540253.2012.755407

Derks, B., Van Laar, C., \& Ellemers, N. (2016). The queen bee phenomenon: Why women leaders distance themselves from junior women. The Leadership Quarterly. https://doi.org/10.1016/j.leaqua.2015.12.007

Dimmock, C., \& Walker, A. (2005). Educational leadership: Culture and diversity. Sage.

Dindoffer, T., Reid, B., \& Freed, S. (2011). Women administrators in Christian universities: Making family and career co-central. Journal of Research on Christian Education, 20(3), 281-308. https://doi.org/10.1080/10656219.2011.624447

Dunn, D., Gerlach, J. M., \& Hyle, A. E. (2014). Gender and Leadership: Reflections of Women in Higher Education Administration. International Journal of Leadership and Change, 2(1), 2.

Eagly, A. H. (2013). Sex differences in social behavior: A social-role interpretation. Psychology Press.

Eagly, A. H., \& Carli, L. L. (2007). Through the labyrinth: The truth about how women become leaders. Harvard Business Press.

Eagly, A. H., \& Johannesen-Schmidt, M. C. (2001). The leadership styles of women and men. Journal of Social Issues, 57(4), 781-797. https://doi.org/10.1111/0022-4537.00241

Eby, L. T. de T., Allen, T. D., Hoffman, B. J., Baranik, L. E., Sauer, J. B., Baldwin, S., ... Curtis, S. (2013). An interdisciplinary meta-analysis of the potential antecedents, correlates, and consequences of protégé perceptions of mentoring. Psychological Bulletin, 139(2), 441. https://doi.org/10.1037/a0029279

Emmett, M. (2001). Women at the heart of a renewed vision for humanity. Agenda, 16(49), 66-70.

Evetts, J. (2014). Women and career: themes and issues in advanced industrial societies. Routledge.

Fagenson, E. A. (1990). At the heart of women in management research: Theoretical and methodological approaches and their biases. Journal of Business Ethics, 9(4-5), 267-274. https://doi.org/10.1007/BF00380326

Fagenson, E. A. (1993). Personal value systems of men and women entrepreneurs versus managers. Journal of Business Venturing, 8(5), 409-430. https://doi.org/10.1016/0883-9026(93)90022-W

Gilligan, C. (2013). Do changes in women's rights change women's moral judgments? The Challenge of Change: Perspectives on Family, Work, and Education, 39-60.

Gmelch, W. H. (2014). Deans' Balancing Acts: Education Leaders and the Challenges They Face.

Gray, L. (2011). An exploratory study of career development and advancement of women towards and into entry executive level in the Canadian Federal Public Service. ProQuest Dissertations and Theses. Retrieved from Group, W. B. (2014). The Little Green Data. World Bank Publications.

Harris, C. A., \& Leberman, S. I. (2011). Leadership development for women in New Zealand universities: Learning from the New Zealand women in leadership program. Advances in Developing Human Resources, 1523422311428747.

Harris, S. L., Wright, S. J., \& Msengi, C. (2011). African American Females' Career Paths to the Presidency: Navigating the Glass Ceiling Challenge. Diversity in Higher Education, 9, 79-98. https://doi.org/10.1108/S1479-3644(2011)0000009009

Harrison, L. E., \& Huntington, S. P. (2000). Culture matters: How values shape human progress. Basic books.

Hartley III, H. V, \& Godin, E. E. (2009). A Study of Career Patterns of the Presidents of Independent Colleges and Universities. Council of Independent Colleges.

Heilman, M. E. (2001). Description and prescription: How gender stereotypes prevent women's ascent up the organizational ladder. Journal of Social Issues, 57(4), 657-674. https://doi.org/10.1111/0022-4537.00234

Heilman, M. E. (2012). Gender stereotypes and workplace bias. Research in Organizational Behavior, 32, 113-135. http://doi.org/10.1016/j.riob.2012.11.003 
Higgins, M. C., \& Kram, K. E. (2001). Reconceptualizing mentoring at work: A developmental network perspective. Academy of Management Review, 26(2), 264-288.

Hoeritz, K. J. (2013). Stereotypes and their consequences for women as leaders in higher education administration. ProQuest Dissertations and Theses. Duquesne University, Ann Arbor.

Hoobler, J. M., Lemmon, G., \& Wayne, S. J. (2014). Women's Managerial Aspirations An Organizational Development Perspective. Journal of Management, 40(3), 703-730. https://doi.org/10.1177/0149206311426911

Hosseini, M. (2008). Women and Higher Education in Islamic Republic of Iran.2008. Tehran: TInstitute for Research \& Planning in Higher Education.

Iannello, K. P. (1995). Decisions Without Hierarchy. Feminist Interventions in Organization Theory and Practice. ORGANIZATION STUDIES-BERLIN-EUROPEAN GROUP FOR ORGANIZATIONAL STUDIES-, 16, 167.

Ismail, M., \& Rasdi, R. M. (2006). Career mobility of high-flying women academics: A study at selected universities in Malaysia. Asia Pacific Journal of Education, 26(2), 155-171. https://doi.org/10.1080/02188790600932111

Johnson, W. B. (2015). On being a mentor: A guide for higher education faculty. Routledge.

Johnsrud, L. K., \& Heck, R. H. (1994). Administrative promotion within a university: The cumulative impact of gender. The Journal of Higher Education, 23-44. https://doi.org/10.2307/2943875

Kiamba, J. M. (2008). Women and Leadership Positions: Social and Cultural Barriers to Success. Wagadu: A Journal of Transnational Women's \& Gender Studies, 6.

Lam, M. P. H. (2009). Senior women academics in Hong Kong: a life history approach. UNIVERSITY OF LEICESTER (UNITED KINGDOM).

Lie, S., \& Malik, L. (2014). World Yearbook of Education 1994: the gender gap in higher education. Routledge.

Luke, C., Gupta, N., Sharma, A. K., Pal, S. A., Villafuerte-Galvez, J., Curioso, W. H., \& Haslegrave, M. (2003). One step up two down: women in higher education management in Southeast Asia. Indian Journal of Gender Studies, 10(2), 285-305.

Mabokela, R. O. (2003). Donkeys of the University: Organizational culture and its impact on South African women administrators. Higher Education, 46(2), 129-145. https://doi.org/10.1023/A:1024754819125

Macfarlane, B. (2013). Intellectual leadership in higher education: Renewing the role of the university professor. Routledge.

Madsen, S. R. (2008). On becoming a woman leader: Learning from the experiences of university presidents (Vol. 124). Wiley. com.

Madsen, S. R. (2012). Women and Leadership in Higher Education Learning and Advancement in Leadership Programs. Advances in Developing Human Resources, 14(1), 3-10. https://doi.org/10.1177/1523422311429668

Martin, J. (1992). Cultures in organizations: Three perspectives. Oxford University Press.

Metz, I. (2003). Individual, interpersonal, and organisational links to women's advancement in management in banks. Women in Management Review, 18(5), 236-251. https://doi.org/10.1108/09649420310485087

Metz, I. (2009). Organisational factors, social factors, and women's advancement. Applied Psychology, 58(2), 193-213. https://doi.org/10.1111/j.1464-0597.2008.00376.x

Ministry of Science, R. and T. (2012). Ministry of Science, Research and Technology. Theran: Institute for Research \& Planning in Higher Education.

Ministry of science, Research and Techonlogy. (2015). Tehran: Institute of Research \& Planing in Higher education.

Morley, L. (2014). Lost leaders: women in the global academy. Higher Education Research \& Development, 33(1), 114-128. https://doi.org/10.1080/07294360.2013.864611

Morrison, A. M., White, R. P., \& Van Velsor, E. (1994). Breaking the glass ceiling: Can women reach the top of America's largest corporations? Basic Books.

Musai, M., Alehashem, B. R., \& Abhari, S. M. F. (2014). Participation of Women in Sociopolitical Development in Iran. International Journal of Academic Research in Business and Social Sciences, 4(3), 571. 
https://doi.org/10.6007/IJARBSS/v4-i3/738

Neale, J., \& Özkanl1, O. (2010). Organisational barriers for women in senior management: a comparison of Turkish and New Zealand universities. Gender and Education, 22(5), 547-563. https://doi.org/10.1080/09540250903524113

Nguyen, T. L. H. (2013). Barriers to and facilitators of female Deans' career advancement in higher education: an exploratory study in Vietnam. Higher Education, 66(1), 123-138. https://doi.org/10.1007/s10734-012-9594-4

Oplatka, I. (2006). Women in educational administration within developing countries: Towards a new international research agenda. Journal of Educational Administration, 44(6), 604-624. https://doi.org/10.1108/09578230610704819

Orser, B., Riding, A., \& Stanley, J. (2012). Perceived career challenges and response strategies of women in the advanced technology sector. Entrepreneurship \& Regional Development, 24(1-2), 73-93. https://doi.org/10.1080/08985626.2012.637355

Ozkanli, A. O., \& Bagilhole, B. (2007). Breaking the Barriers to women achieving seniority in Universities, (August).

Pai, K., \& Vaidya, S. (2009). Glass ceiling: role of women in the corporate world. Competitiveness Review: An International Business Journal, 19(2), 106-113. https://doi.org/10.1108/10595420910942270

Parker, B., \& Fagenson, E. A. (1994). An introductory overview of women in corporate management. Women in Management: Current Research Issues, 11-25.

Parker, M., \& Welch, E. W. (2013). Professional networks, science ability, and gender determinants of three types of leadership in academic science and engineering. The Leadership Quarterly, 24(2), 332-348. https://doi.org/10.1016/j.leaqua.2013.01.001

Peterson, H. (2014). An Academic "Glass Cliff"? Exploring the Increase of Women in Swedish Higher Education Management. Athens Journal of Education, 1(1), 32-44.

Probert, B. (2005). I just couldn't fit it in: Gender and unequal outcomes in academic careers. Gender, Work \& Organization, 12(1), 50-72. https://doi.org/10.1111/j.1468-0432.2005.00262.x

Rafnsdóttir, G. L., \& Heijstra, T. M. (2013). Balancing work-family life in academia: The power of time. Gender, Work \& Organization, 20(3), 283-296. https://doi.org/10.1111/j.1468-0432.2011.00571.x

Ragins, B. R., \& Sundstrom, E. (1989). Gender and power in organizations: A longitudinal perspective. Psychological Bulletin, 105(1), 51. https://doi.org/10.1037/0033-2909.105.1.51

Ramsay, K., \& Letherby, G. (2006). The experience of academic non - mothers in the gendered university. Gender, Work \& Organization, 13(1), 25-44. https://doi.org/10.1111/j.1468-0432.2006.00294.x

Rezai-Rashti, G. M., \& Moghadam, V. M. (2011). Women and higher education in Iran: What are the implications for employment and the "marriage market"? International Review of Education, 57(3-4), 419-441. https://doi.org/10.1007/s11159-011-9217-9

Riger, S., \& Galligan, P. (1980). Women in management: An exploration of competing paradigms. American Psychologist, 35(10), 902. https://doi.org/10.1037/0003-066X.35.10.902

Rosser, S. V. (2004). The science glass ceiling: Academic women scientists and the struggle to succeed. Psychology Press. https://doi.org/10.4324/9780203354612

Rosser, V. J. (2003). Faculty and Staff Members' Perceptions of Effective Leadership: Are There Differences Between Women and Men Leaders? Equity \&Excellence in Education, 36(1), 71-81. https://doi.org/10.1080/10665680303501

Schein, V. E. (2001). A global look at psychological barriers to women's progress in management. Journal of Social Issues, 57(4), 675-688. https://doi.org/10.1111/0022-4537.00235

Shah, S., \& Sobehart, H. (2008). Women and educational leadership in a Muslim society. Women Leading Education across the Continents: Sharing the Spirit, Fanning the Flame, 344-381.

Shahtalebi, S., \& Yarmohammadian, M. H. (2012). Barriers to Women Managers Climb the Peaks of Success. Procedia - Social and Behavioral Sciences, 46, 3088-3092. https://doi.org/10.1016/j.sbspro.2012.06.016

Shakeshaft, C. (1989). Women in educational administration. ERIC. 
Staines, G., Tavris, C., \& Jayaratne, T. E. (1974). The queen bee syndrome. Psychology Today, 7(8), 55-60.

Stalker, J. (2013). Women mentoring women in the academy'. From Adult Education to the Learning Society: 21 Years of the International Journal of Lifelong Education, 210.

Steinke, K. (2006). Madwoman, queen, and alien-being: The experiences of first-time women presidents at small private colleges. Bowling Green State University.

Tharenou, P. (2001). Going up? Do traits and informal social processes predict advancing in management? Academy of Management Journal, 44(5), 1005-1017. https://doi.org/10.2307/3069444

Tharenou, P., Latimer, S., \& Conroy, D. (1994). How do you make it to the top? An examination of influences on women's and men's managerial advancement. Academy of Management Journal, 37(4), 899-931. https://doi.org/10.2307/256604

Turner, C. S. V., \& González, J. C. (2011). Faculty women of color: The critical nexus of race and gender. Journal of Diversity in Higher Education, 4(4), 199. https://doi.org/10.1037/a0024630

Umbach, P. D. (2006). The contribution of faculty of color to undergraduate education. Research in Higher Education, 47(3), 317-345. https://doi.org/10.1007/s11162-005-9391-3

Vinkenburg, C. J., van Engen, M. L., Eagly, A. H., \& Johannesen-Schmidt, M. C. (2011). An exploration of stereotypical beliefs about leadership styles: is transformational leadership a route to women's promotion? The Leadership Quarterly, 22(1), 10-21. https://doi.org/10.1016/j.leaqua.2010.12.003

Wagner, H., Kim, A. J., \& Gordon, L. (2013). The Relationship between Personal Protective Equipment (PPE), Self-Efficacy, and Job Satisfaction of Women in the Building Trades. Journal of Construction Engineering and Management. https://doi.org/10.1061/(ASCE)CO.1943-7862.0000739

Wajcman, J. (2013). Managing like a man: Women and men in corporate management. John Wiley \& Sons.

Walts, B. (2012). A qualitative study of the role of female to female mentorship on women's career development. UNIVERSITY OF PHOENIX.

Welch, A. (2011). Higher education in Southeast Asia: Blurring borders, changing balance. Taylor \& Francis.

White, K., Bagilhole, B., \& Riordan, S. (2012). The gendered shaping of university leadership in Australia, South Africa and the United Kingdom. Higher Education Quarterly, 66(3), 293-307. https://doi.org/10.1111/j.1468-2273.2012.00523.x

White, K., Carvalho, T., \& Riordan, S. (2011). Gender, power and managerialism in universities. Journal of Higher Education Policy and Management, 33(2), 179-188. https://doi.org/10.1080/1360080X.2011.559631

Wolverton, M., \& Gmelch, W. H. (2002). College Deans: Leading from within. American Council on Education/Oryx Press Series on Higher Education. ERIC.

Wood, D. F., Dean, D. R., Bracken, S. J., \& Allen, J. K. (2009). Barriers to women's leadership in faith-based colleges and universities. Women in Academic Leadership, 74-94.

Yukongdi, V., \& Rowley, C. (2009). The changing face of women managers in Asia: opportunities and challenges.

\section{Copyrights}

Copyright for this article is retained by the author(s), with first publication rights granted to the journal.

This is an open-access article distributed under the terms and conditions of the Creative Commons Attribution license (http://creativecommons.org/licenses/by/4.0/). 